\title{
1. A Patient with Organizing Pneumonia Development During the Use of Capecitabine Maintenance Treatment for Gastric Cancer
}

\author{
Mide Kanseri için Idame Kapesitabin Tedavisi Kullanan Bir Hastada \\ Gelişen Organize Pnömoni Olgusu
}

Gökmen Aktaş' ', Tülay Kuş' ${ }^{1}$, Mehmet Emin Kalender', Kemal Bakır², Celaletdin Camcı'

\begin{abstract}
Organizing pneumonia (OP) is an inflammatory process of the bronchioles that can lead to destruction of small airways and surrounding lung tissue. Secondary OP, caused by anti-cancer drugs and radiotherapy, has previously been reported. In this study, we report the case of a 60-year-old female patient presented with $\mathrm{OP}$, while using low dose capecitabine maintenance for stage IV gastric cancer under remission. After 18 months of routine follow-up with computed tomography (CT), a $9 \mathrm{~mm}$ subpleural nodule was presented at the right lung upper lobe posterior segment. Wedge resection was performed. Based on histopathologic examination, a diagnosis of OP was confirmed. In this instance, capecitabine was implicated as the likely cause of this drug-induced lung toxicity. This patient is the first case associated with development of OP during capecitabine monotherapy.
\end{abstract}

Key words: Organizing pneumonia, capecitabine, solitary nodule, gastric cancer.

\section{Özet}

Organize pnömoni (OP) küçük havayolları ve etrafındaki dokularda hasara yol açabilen bronşiollerin inflamatuvar bir sürecidir. Antikanser ilaçlar ve radyoterapiye bağlı sekonder OP daha önce bildirilmiştir. Bu makalede, remisyonda evre 4 mide kanseri nedeniyle idame düşük doz kapesitabin kullanırken OP gelişen 60 yaşında bir kadın hasta sunulmuştur. On sekiz ay süresine kapesitabin tedavisi altında iken rutin bilgisayarlı tomografi tetkikinde sağ akciğer üst lob posterior segmentte $9 \mathrm{~mm}$ subplevral nodül saptanmış ve kama rezeksiyon uygulanmıştır. Histopatolojik incelemede OP tanısı koyulmuştur. Bu durum ilaç ilişkili akciğer toksisitesi olarak düşünülmüştür. Bu hasta uzun süreli kapesitabin monoterapisi altında OP gelişen literatürdeki ilk olgudur.

Anahtar Sözcükler: Organize pnömoni, kapesitabin, soliter nodül, gastrik kanser.
'Department of Internal Medicine, Division of Oncology, Gaziantep University, Gaziantep, Turkey

${ }^{2}$ Department of Pathology, Gaziantep University, Gaziantep, Turkey
'Gaziantep Üniversitesi, İç Hastalıkları Anabilim Dalı, Tıbbi Onkoloji Bilim Dalı, Gaziantep

${ }^{2}$ Gaziantep Üniversitesi, Patoloji Anabilim Dalı, Gaziantep

Submitted (Başvuru tarihi): 16.07.2015 Accepted (Kabul tarihi): 31.08.2015

Correspondence (iletişim): Gökmen Aktaş, Department of Internal Medicine, Division of Oncology, Gaziantep University, Gaziantep, Turkey

e-mail: aktas_gokmen@hotmail.com

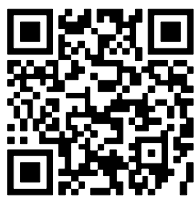


Incidences of gastric cancer are showing an upward trend in many countries and the disease is the fourth most common cancer worldwide (1). Gastric cancer is an aggressive malignancy, often diagnosed at an advanced stage and the five-year overall survival rate is approximately $22 \%$ (2). Maintenance treatment is recommended for patients who responded to the combination therapy in metastatic disease. The efficacy of maintenance treatment of gastric cancer is not clear. One prospective observational study showed that capecitabine, as maintenance treatment after first-line chemotherapy in advanced gastric adenocarcinoma, provides the advantage of progression- free survival, and offers a reliable and safe option (3).

Capecitabine is an orally administered fluoropyrimidine agent converted to 5 -flurouracil (5-FU) in multiple steps, involving the enzyme thymidine phosphorylase, which is found at much higher levels in gastric cancer tissue than in normal tissue (4). Hand-foot syndrome, nausea, vomiting, anorexia, stomatitis and diarrhea are the most common adverse events (5). The most common respiratory side effects are dyspnea (14\%) and cough (7\%).

Several chemotherapy agents such as bleomycin, busulfan, methotrexate and cyclophosphamide have been associated with lung toxicity including diffuse alveolar damage, hypersensitivity pneumonitis, organizing pneumonia, nonspecific interstitial pneumonia, and eosinophilic pneumonia but lung toxicity with capecitabine is uncommon $(6,7)$. There are some pulmonary toxicity patterns with capecitabine at the literature. These are, ILD with a granulomatous component due to capecitabine and sarcoid-like granulomatous inflammation. In this case report we present the first case of OP associated with capecitabine monotherapy in a patient with metastatic gastric cancer with confirmed remission state.

\section{CASE}

A 60-year-old female patient presented with fatigue, epigastric pain and weight loss. Upper endoscopic examination revealed an ulcerative mass about $4 \mathrm{~cm}$ in the gastric antrum. Endoscopic biopsy evaluated as gastric adenocarcinoma in March 2010. An abdominal computed tomography (CT) scan showed no distant metastasis. Distal subtotal gastrectomy and lymph nodes dissection were performed. Pathological examination showed intestinal type moderately differentiated adenocarcinoma with subserosal invasion and metastatic involvement in three of 38 lymph nodes. Postoperative pathhological staging was $\mathrm{pT} 2 \mathrm{bN} 1 \mathrm{MO}$. Adjuvant chemo-radiotherapy with 5 fluorouracil/leucovorin was administered. After six months, multiple peritoneal metastases were detected in positron emission tomography-computed tomography (PET-CT) scan. She received docetaxel $60 \mathrm{mg} \backslash \mathrm{m}^{2}$ day 1 , cisplatin $50 \mathrm{mg} \backslash \mathrm{m}^{2}$ day 1 and 8,5 -flourouracil $1000 \mathrm{mg} \backslash \mathrm{m}^{2}$ day 1 to 5 once every three weeks for six cycles. After this chemotherapy, partial response was observed in PET-CT and the patient's treatment was changed to cisplatin $55 \mathrm{mg} \backslash \mathrm{m}^{2}$ day 1 , capecitabine $2000 \mathrm{mg} \backslash \mathrm{m}^{2}$ day 1 to 14 once every three weeks for three cycles. Complete remission was confirmed by a PET-CT scan following this chemotherapy and capecitabine $1000 \mathrm{mg} \backslash \mathrm{m}^{2} \backslash$ day was initiated as maintenance treatment. After eighteen months under remission, during a routine CT scan, a $9 \mathrm{~mm}$ sized irregular bordered nodular opacity was observed in the right lung superior lobe posterior segment, which was surrounded by opal glass density areas (Figure 1). The patient had no drug toxicity or pulmonary symptoms. At the previous CT scan, there was no lesion, supporting evidence of the new lesion probably being metastases. The patient underwent a pulmonary metastasectomy due to single organ involvement with single lesion recurrence, and estimated survival advantage. Wedge resection was performed. Histopathological diagnosis was reported as OP (Figure 2). The patient is still in remission.

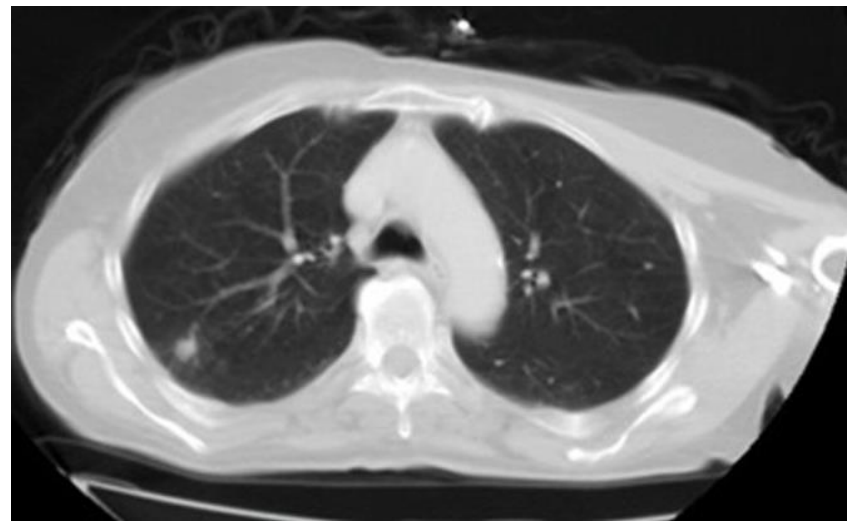

Figure 1: A CT scan of thorax with contrast showing $9 \mathrm{~mm}$ sized irregular bordered nodular opacity in the right lung upper lobe posterior segment that was surrounded by ground glass density areas

\section{DISCUSSION}

The idiopathic form of organizing pneumonia, called cryptogenic $O P$, is a type of diffuse interstitial lung disease that affects the distal bronchioles, respiratory bronchioles, alveolar ducts and alveolar walls. Secondary OP can be seen in association with connective tissue diseases, drugs, malignancy, and other interstitial pneumonias (8). 
Oncologic OP cases are usually observed following radiotherapy for breast cancer or on rare occasions reported after chemotherapy with paclitaxel, oxaliplatin, 5- FU with oxaliplatin (FOLFOX regime), gemcitabine and some targeted agents (9-17).

The true incidence and prevalence of OP are unknown. In a 20-year review of national statistics for Iceland, the mean annual incidence of OP was 1.1 per 100,000. Onset of $O P$ is generally in the fifth or sixth decade of life and men and women are affected equally (18). Histopathologic lesion characteristics of $\mathrm{OP}$ include excessive proliferation of granulation tissue, and consist of loose collagen-embedded fibroblasts and myofibroblasts, involving alveolar ducts and alveoli. It is suggested that bronchiolar lesions reflect the extension of intraluminal plugs of granulation tissue from alveolar sacs and ducts to the bronchioles. Pathologic lesions are predominantly within the airspace as well as mild chronic inflammation (e.g., lymphocytes and plasma cells) is present in the alveolar walls (19).
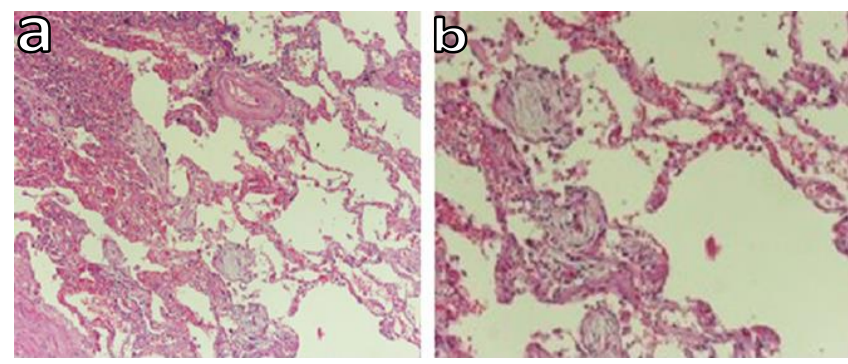

Figure 2a, b: At the pathological examination there were intraluminal plugs of granulation tissue, peribronchial lung parenchyma with intraalveolar fibrosis. Histopathologic diagnosis is organizing pneumonia. (Hematoxylin and eosin stain, original magnification $\times a: 100-b: 200$ )

OP typically presents with cough, dyspnea, fever and malaise. In most patients, symptoms are typically presented in less than two months. In one-half of patients, onset appears with the acute onset of a flu-like illness with fever, malaise, fatigue, and cough, but in other patients the onset of symptoms is less acute (20). Radiographic patterns include patchy consolidation, ground-glass opacities, nodular opacities, and bronchial wall thickening. Patchy opacities occur more generally on the periphery of the lung and in the lower lung zone. Rarely, it is present as a single nodule; when it is termed focal organizing pneumonia $(21,22)$.

In the literature, after four cycles of oxaliplatin, capecitabine and bevacizumab one patient experienced clinically acute respiratory distress with radiological findings of bilateral, ground-glass opacifications and consolidation. Pulmonary findings showed resolution after the removal of oxaliplatin from the treatment and replacement with irinotecan. Thus, these clinical findings are associated with oxaliplatin use (23). Similar cases are frequently represented with symptomatic and hazardous progress.

In this case, a patient with stage IV gastric cancer who is under remission and using capecitabine $1000 \mathrm{mg} \backslash \mathrm{m}^{2}$ for maintenance therapy is presented. Unlike the oncological cases in the literature, this patient did not exhibit an acute presentation. Also, unlike the cases in the literature, because of the differential diagnosis of the solitary pulmonary nodule includes metastatic lesion, metastasectomy was performed (9-17). Histopathological diagnosis was reported as OP. In differential diagnosis, prior infection, toxic inhalants, connective tissue diseases (SLE,RA), other drug reactions, other interstitial pneumonias and radiation injury were excluded. According to the Naranjo adverse drug reaction probability scale (ADR), it is accepted to be $\mathrm{OP}$, secondary to long-term capecitabine treatment. According to the ADR scale, the score was six and defined as probable drug toxicity (24).

\section{CONCLUSION}

This is the first case of $O P$ in the English literature as a result of using capecitabine maintenance. This case report is an example supporting the logic of considering OP for the differential diagnosis of malignancy recurrence of patients who have single nodulary metastasis, in the absence of other recurrence sign. Thereby, especially patients with gastrointestinal system cancer at remission, $O P$ should not be excluded in the differential diagnoses of patients who develop pulmonary nodule, because of the mimicking of nodular metastasis by OP.

\section{CONFLICTS OF INTEREST}

None declared.

\section{AUTHOR CONTRIBUTIONS}

Concept - G.A., T.K., M.E.K., K.B., C.C.; Planning and Design - G.A., T.K., M.E.K., K.B., C.C.; Supervision G.A., T.K., M.E.K., K.B., C.C.; Funding -; Materials -; Data Collection and/or Processing - G.A., T.K., K.B.; Analysis and/or Interpretation - G.A., T.K., C.C.; Literature Review - G.A., T.K., M.E.K., K.B.; Writing - G.A., T.K., M.E.K.; Critical Review - C.C., M.E.K.

\section{YAZAR KATKILARI}

Fikir - G.A., T.K., M.E.K., K.B., C.C.; Tasarım ve Dizayn G.A., T.K., M.E.K., K.B., C.C.; Denetleme - G.A., T.K., M.E.K., K.B., C.C.; Kaynaklar -; Malzemeler -; Veri Top- 
lama ve/veya İşleme - G.A., T.K., K.B.; Analiz ve/veya Yorum - G.A., T.K., C.C.; Literatür Taraması - G.A., T.K., M.E.K., K.B.; Yazıyı Yazan - G.A., T.K., M.E.K.; Eleştirel Inceleme - C.C., M.E.K.

\section{REFERENCES}

1. Kamangar F, Dores GM, Anderson WF. Patterns of cancer incidence, mortality, and prevalence across five continents: defining priorities to reduce cancer disparities in different geographic regions of the world. J Clin Oncol 2006; 24:2137-50. [CrossRef]

2. Wang SJ, Emery R, Fuller CD, Kim JS, Sittig DF, Thomas CR. Conditional survival in gastric cancer: a SEER database analysis. Gastric Cancer 2007; 10:153-8. [CrossRef]

3. Qiu MZ, Wei XL, Zhang DS, Jin Y, Zhou YX, Wang DS, ef al. Efficacy and safety of capecitabine as maintenance treatment after first-line chemotherapy using oxaliplatin and capecitabine in advanced gastric adenocarcinoma patients: a prospective observation. Tumour Biol 2014; 35:4369-75. [CrossRef]

4. Quek R, Lim WT, Foo KF, Koo WH, A-Manaf A, Toh HC. Capecitabine and oxaliplatin (XELOX) is safe and effective in patients with advanced gastric cancer. Acta Oncol 2007; 46:1032-4.

5. Hong YS, Song SY, Lee SI, Chung HC, Choi SH, Noh SH, et al. A phase II trial of capecitabine in previously untreated patients with advanced and/or metastatic gastric cancer. Ann Oncol 2004; 15:1344-7. [CrossRef]

6. Sleijfer S. Bleomycin-induced pneumonitis. Chest 2001; 120:617-24. [CrossRef]

7. Kim YJ, Song M, Ryu JC. Mechanisms underlying methotrexate-induced pulmonary toxicity. Expert Opin Drug Saf 2009; 8:451-8. [CrossRef]

8. Cordier JF. Organising pneumonia. Thorax 2000; 55:318-28.

9. Barjaktarevic IZ, Qadir N, Suri A, Santamauro JT, Stover D. Organizing pneumonia as a side effect of ipilimumab treatment of melanoma. Chest 2013; 143:858-61. [CrossRef]

10. Garrido M, O'Brien A, González S, Clavero JM, Orellana E. Cryptogenic organizing pneumonitis during oxaliplatin chemotherapy for colorectal cancer: case report. Chest 2007; 132:1997-9. [CrossRef]

11. Kawsar HI, Spiro TP, Cocco A, Daw HA. BOOP as a rare complication of gemcitabine therapy. BMJ Case Rep 2011 Jul 20;2011. [CrossRef]

12. Shogbon AO, Hap J, Dretler R, Dalvi AG. Cryptogenic organizing pneumonia during adjuvant chemotherapy with oxaliplatin, 5-fluorouracil, and leucovorin (FOLFOX) for colon cancer. J Pharm Pract 2013; 26:62-6. [CrossRef]

13. Dahlqvist C, Fremault A, Carrasco J, Colinet B. Obliterative bronchiolitis with organising pneumonia following FOLFOX 4 chemotherapy. Rev Mal Respir 2010; 27:847. [CrossRef]

14. Hasskarl J, Schroettner P, von den Berg A, Rueckert A, Frydrychowicz $A$, Kayser $G$, et al. Severe organizing pneumonia after two cycles of docetaxel as fourth-line chemotherapy for advanced non-small cell carcinoma of the lung. Case Rep Oncol 2009; 2:12-9.

15. Santana AR, Amorim FF, Soares PH, Moura EB, Maia Mde $O$. Acute respiratory failure caused by organizing pneumonia secondary to antineoplastic therapy for nonHodgkin's lymphoma. Rev Bras Ter Intensiva 2012; 24:415-9.

16. Asai N, Yokoi T, Yamaguchi E, Kubo A. Successful crizotinib rechallenge after crizotinib-induced organizing pneumonia in anaplastic lymphoma kinase-rearranged nonsmall cell lung cancer. Case Rep Oncol 2014; 7:681-4. [CrossRef]

17. Chua W, Peters M, Loneragan R, Clarke S. Cetuximabassociated pulmonary toxicity. Clin Colorectal Cancer 2009; 8:1 18-20. [CrossRef]

18. Gudmundsson $G$, Sveinsson $O$, Isaksson HJ, Jonsson $S$, Frodadottir $\mathrm{H}$, Aspelund T. Epidemiology of organising pneumonia in Iceland. Thorax 2006; 61:805-8. [CrossRef]

19. Costabel U, Teschler H, Guzman J. Bronchiolitis obliterans organizing pneumonia (BOOP): the cytological and immunocytological profile of bronchoalveolar lavage. Eur Respir J 1992; 5:791-7.

20. Oymak FS, Demirbaş HM, Mavili E, Akgun H, Gulmez I, Demir $R$, et al. Bronchiolitis obliterans organizing pneumonia. Clinical and roentgenological features in 26 cases. Respiration 2005; 72:254-62.

21. Lee JW, Lee KS, Lee HY, Chung MP, Yi CA, Kim TS, et al. Cryptogenic organizing pneumonia: serial highresolution CT findings in 22 patients. AJR Am J Roentgenol 2010; 195:916-22. [CrossRef]

22. Melloni G, Cremona G, Bandiera A, Arrigoni G, Rizzo N, Varagona $R$, et al. Localized organizing pneumonia: report of 21 cases. Ann Thorac Surg 2007; 83:1946-51. [CrossRef]

23. Fekrazad MH, Eberhardt S, Jones DV, Lee FC. Development of bronchiolitis obliterans organizing pneumonia with platinum-based chemotherapy for metastatic rectal cancer. Clin Colorectal Cancer 2010; 9:177-8. [CrossRef] 
24. Naranjo CA, Busto U, Sellers EM, Sandor P, Ruiz I, Roberts $E A$, et al. A method for estimating the probability of advers drug reactions. Clin Pharmacol Ther 1981; 30:239-45. 